\title{
The Meaning of Verse 34 of Surah An-Nisa in Quran: No to Violence
}

\author{
Dr. Zahra Besharati \\ $\mathrm{PhD}$ of Theology in Quran and Hadith, Graduated from Allameh Tabataba'i University, Tehran, Iran \\ Miracle of Quran Research Center, Shahid Beheshti University, Tehran, Iran \\ Dr. Mohammad Reza Shahroudi \\ Associate Professor of Theology in Quran and Hadith, Faculty of Theology, University of Tehran, Tehran, Iran \\ Mohammad Reza Besharati, besharati@ce.sharif.edu \\ Graduated from Sharif University of Technology, Tehran, Iran \\ Miracle of Quran Research Center, Shahid Beheshti University, Tehran, Iran
}

\begin{abstract}
The keywords of Verse 34 of Surah An-Nisa come with various meanings, each of which enables us to know a distinct aspect, meaning and matter. Each aspect, i.e., meanings proposed by commentators, translators, and scholars throughout history for this verse, is according to a distinct wonted system of the family in history. "Zarb (Darb)" does not mean assault or any form of violence against women. Rather, it means a practical action to inspire disobedient women to obey the legitimate rights of their spouse.
\end{abstract}

\section{Keywords}

Women, Men, Quran, Zarb, Darb, Family Law, Denial of Violence against Women

\section{Introduction}

Many systems have governed families in history depending on the custom of various communities and generations[1]. The respectable Verse 34 of Surah An-Nisa attempts to show a solution for the "Unjustifiable Disobedience of Wife to Husband's legitimate rights[2], mostly in sexual aspect of marital relationship [2]" (Arabic: Noshooz al-Zowjah). [Likwise, a verse in the Surah An-Nisa, Verse 128, is to show a solution for unjustifiable refusal of husband to fulfill any of his regular or routine duties to his wife's legitimate rights during marital relationship].

Keywords of Verse 34 of Surah An-Nisa come with various meanings, each of which enables us to know a distinct aspect and matter [7]. Each aspect below, i.e., meanings proposed by commentators, translators, and scholars throughout history for this verse, is according to a distinct wonted system of the family in history:

1. Men are the caregivers of women and can advise them if they see ill-conduct from their women. And if women persist, men can discipline them gently. This meaning is according to the conventional system of patriarchy and masculism in the family. This approach has expired in the modern-world of societies [2].

2. Men hold the family headship and are in charge of women in family affairs, alimony, and necessaries. When dealing with disobedience by women, men can advise them first, and if persist, discipline them with a gentle "Zarb (Darb)" (Knok) [Arabic: Azreboohonna (Knock them)] [3], for example by a toothbrush [6] and a similar object. This meaning is according to the concept of participation and cooperation with emphasizing the men's headship.

3. Men are the caretakers of women and have been provisioned over women and tasked with supporting them in family affairs and alimony [4]. When dealing with disobedience by women, men should advise them first. And if persist, they must take practical action [1] [5], , without any form of violence [1], e.g., stop to give alimony, leaving and separation, travel, more love for inspiring woman's withdrawal from disobedience, or other meanings cited by this group of researchers. This meaning is according to the general system of "Supportive Man-Dependent Woman", or the conventional system of the family in the 20 th century in the West and more recently in Iran. 
4. Men and women are interdependent and corresponding to each other [2]. At disobedience, men must advise women first. Then, if persist, they should convert the situation of disobedience (Arabic: Noshooz) by practical action (Arabic: Azreboohonna), without any form of violence [2]. In simple terms, men must conduct with disobedient women so that they either retreat and gave up or were convinced, or abide by the right with men. This is a new meaning, and contrary to the previous ones, is not well established and researched.

This meaning is according to the family system of the 21st-century in the West, which implies that men and women are intertwined and the family is as a whole, as well as the Sadraei approach in East, i.e., acceptance of differences and following justice.

\section{Polysemous Order}

As described, each of the above systems has been popular in one era and was a norm in a generation (Treat them fairly; [Arabic: Asheroohan'n Bil Ma'ruf]). It is expected if this respectable verse and The Sacred, Supreme Lawgiver (the Allah [8]) have attempted to explain only one of the above meanings. Likewise, it is assumed that the sacred lawgiver may followed a prepared version [as, according to Ayatollah Maaref for the prepared version [9], it has been tried to gradually replace the culture of assault and violence against women with the culture of "Zarb (Darb)" (Knocking gently)) [1]. And that various meanings are successive steps of the prepared version.

And whether or not this respectable verse has reflected the custom of the society and has declaimed, by an occult understanding of the developments of the custom of the society in the next 1500 years, so that it is feasible to get a distinct meaning according to the concept of "Applicability and Comparison" [10] for each customary system. That is, we are here with a polysemous order in which each meaning is linked to fixing "disobedience" in any distinct customary system, along the path of historical culturetransformations. This evolutionary semantic feature of revelation is in accordance with evolution of human societies and norms.

\section{Conclusion}

Therefore, this respectable verse might be deemed to hold a semantic polysemous order, and applicability and comparison, as well as a prepared version. According to the results of the article [1], "Zarb (Darb)" does not mean assault or any form of violence against women. Rather, it means a practical action to inspire disobedient women to obey the legitimate rights of their spouse [1].

\section{Acknowledgment}

This article was prepared by using and reviewing various articles. The article [1] is about determining the meaning of "Zarb (Darb)" in Verse 34 of Surah An-Nisa.

\section{References}

[1] Shahroodi, Mohammad Reza, and Zahra Besharati. "Reciting of Women Beating in An-nisa'verse: 34." Jurisprudence the Essentials of the Islamic Law 53, no. 1 (2020): 125-144. https://jifil.ut.ac.ir/article_78629.html?lang=en

[2] Moosavi, Bojnourdi Sayed Mohammad, And Seyedeh Shahnaz Hosseini. "A Study Of Disobedience Of Wife In Jurisprudence And Law With Emphasis On Imam Khomeini's Viewpoint." (2016): 27-46.

[3] Makarem Shirazi, N. "Holy Quran translation." Qum: Dar al-Quran Karim (1994).

[4] Saffarzadeh, Tahereh. "The holy Quran: Translation with commentary." (2006).

[5] al-Farāhidī, Kholīl Ibn Ahmad. "Kitāb al-'Ain." Bairut-Libanon: Dār al-Kutub al- 'Ilmiah (1996).

[6] Majlisi, Muhammad Baqir. "Bihar al-anwar." Beirut: Al-Wafa (1983): 227.

[7] Besharati, MohammadReza, and Mohammad Izadi. "DAST Model: Deciding About Semantic Complexity of a Text." arXiv preprint arXiv:1908.09080 (2019). 
[8] Feridon, Hassan. "The flexibility of Shariah (Islamic law) with reference to the Iranian experience." PhD diss., Glasgow Caledonian University, 1998.

[9] Basiri, H. R., and Z. Besharati. "Analysis of Corporal Punishment of Children in the Family based on the Semantic Reading of Traditional Islamic Narratives including the Word "Dharb"[Hitting]." (2016): 93-113.

[10] Tabatabai, Muhammad Hussein. "al-Mizan." Beirut: Academic Press Co 1403 (1995): 353. 